\title{
PENGARUH PENAMBAHAN LIMBAH PLASTIK TERHADAP KARAKTERISTIK CAMPURAN ASPAL AC-WC
}

\author{
Amelia Wijayanti ${ }^{1}$, Iphan Fitrian Radam ${ }^{2 *}$ \\ 1) Program Studi Teknik Sipil Universitas Lambung Mangkurat (email: \\ ameliawijayanti99@gmail.com) \\ 2) PSMTS Universitas Lambung Mangkurat (email: ifradam@ulm.ac.id)
}

\author{
Info Artikel \\ Riwayat Artikel: \\ Dikirim :21-12-21 \\ Direvisi :27-12-21 \\ Diterima :31-12-21

\section{Kata Kunci :} \\ Campuran Beraspal \\ Low Density \\ Polyethylene \\ Stabilitas Marshall
}

\begin{abstract}
$\underline{\text { ABSTRAK }}$
Untuk mengurangi jumlah kebutuhan aspal sebagai bahan dasar, maka dicari bahan tambahan contohnya menggunakan plastik. Bahan yang digunakan adalah limbah plastik jenis LDPE (Low Density Polyethylene). Plastik LDPE memiliki sifat mudah diproses, kuat, fleksibel, kedap air, tembus cahaya dan melunak pada suhu $70^{\circ} \mathrm{C}$. Campuran aspal menggunakan plastik ini akan di uji di labolatorium untuk mencari nilai-nilai campuran beraspal panas dengan metode Marshall Tes. Pada penelitian ini dicoba dengan variasi persentase plastik yaitu $0 \%, 3 \%, 6 \%, 9 \%, 12 \%$, dan $20 \%$ dari berat aspal. Penelitian ini bertujuan untuk mengetahui kadar optimum aspal AC-WC, kadar optimum aspal plastik dan perbedaan hasil uji marshall antara aspal biasa dengan aspal plastik. Nilai KAO pada aspal AC-WC didapatkan sebesar 6,125\% dan nilai KAO untuk aspal plastik didapatkan sebesar 7,45\%. Pada nilai density,Flow, dan VFB didapatkan aspal tanpa plastik lebih besar dibandingkan yang menggunakan plastik. Sedangkan nilai stabilitas, VIM, VMA, dan MQ aspal tanpa plastik lebih kecil dibandingkan yang menggunakan plastik.
\end{abstract}

\section{PENDAHULUAN}

Pesatnya pertambahan penduduk ini mengakibatkan perkerasan jalan semakin cepat rusak dikarenakan jalan yang kurang dapat menampung beban/kapasitas untuk kendaran yang melewati jalan tersebut. Selain dari faktor tersebut, cuaca juga menjadi penyebab aspal menjadi mudah lapuk dan rusak seperti cuaca kita di Indonesia ini yaitu panas yang menyebabkan adanya oksidasi oleh sinar matahari dan hujan yang menyebabkan aspal menjadi lembab. Maraknya perdagangan secara online juga banyak menggunakan plastik untuk membungkus barang-barang yang akan dikirimkan kepada pembeli agar barang-barang tersebut tetap aman dan tidak lecet. Berdasarkan penelitian yang dilakukan oleh Jenna $R$. Jambeck dari University of Georgia, pada Tahun 2010 ada 275 juta ton sampah plastik yang diha- silkan di seluruh dunia. Sekitar 4,8-12,7 juta ton diantaranya terbuang dan mencemari laut.

Aspal merupakan salah satu material yang digunakan sebagai bahan pembuatan jalan raya, material ini memiliki hasil akhir yang baik dan nyaman sebagai perkerasan fleksibel. Untuk mengurangi jumlah kebutuhan aspal sebagai bahan dasar, maka dicari bahan tambahan yang dalam pencampuran sifatnya mampu mengatasi kelemahan yang dimiliki aspal contohnya menggunakan plastik. Penambahan plastik terhadap campuran aspal merupakan salah satu solusi yang diharapkan mampu meningkatkan stabilitas campuran aspal.

Bahan plastik yang digunakan adalah merupakan limbah plastik jenis Low Density Polyethylene (LDPE) yaitu jenis limbah plastik seperti kantong plastik yang telah di sortir, di 
bersihkan, dan dicacah menggunakan mesin. Campuran aspal dengan menggunakan plastik ini akan di uji di labolatorium untuk mencari nilainilai campuran beraspal panas dengan metode Marshall Tes. Pada penelitian ini akan dicoba persentase yang berbeda dari penelitianpenelitian sebelumnya dengan variasi persentase plastik yaitu $0 \%, 3 \%, 6 \%, 9 \%, 12 \%$, dan $20 \%$ dari berat aspal. Dari data hasil pengujian maka akan didapatkan perbedaan aspal plastik dengan aspal biasa dan perbedaan dari variasi persentase dari percobaan sebelumnya.

Secara umum tujuan dalam penelitian ini adalah mengetahui kadar optimum campuran beraspal AC-WC tanpa dan dengan tambahan plastik LDPE, serta mendapatkan pengaruh dari kombinasi kedua jenis aspal tersebut.

\section{TINJAUAN PUSTAKA}

\subsection{Bahan Campuran Aspal}

Campuran aspal panas adalah suatu campuran perkerasan jalan lentur yang terdiri dari agregat kasar, agregat halus, filler, dan bahan pengikat aspal dengan perbandingan- perbandingan tertentu dan dicampurkan dalam kondisi panas. Perkerasan jalan raya adalah bagian jalan raya yang diperkeras dengan lapis konstruksi tertentu, yang memiliki ketebalan, kekuatan, dan kekakuan, serta kestabilan tertentu agar mampu menyalurkan beban lalu lintas diatasnya ke tanah dasar secara aman. Untuk mendapatkan suatu campuran aspal yang baik dilakukan suatu percobaan di laboratorium antara agregat, filler, dan aspal. Agregat yang kecil akan mengisi ruang antara agregat yang lebih besar membentuk susunan yang padat dan untuk mempercepat proses adhesi antara penyusun bahan ditambahkan zat aditif (Gunawan, 2001).

\subsection{Agregat \\ 1. Agregat Kasar}

Agregat kasar yaitu batuan yang tertahan disaringan 2,36 $\mathrm{mm}$ atau sama dengan saringan no.8 standar ASTM. Keuntungan agregat kasar menyebabkan rongga udara meningkat sehingga air mudah masuk dan daya lekatnya menurun (Sukirman, 2003). Persyaratan spesifikasi agregat kasar yang memenuhi standar diatur berdasarkan Tabel 1.

Tabel 1. Ketentuan Agregat Kasar

\begin{tabular}{|c|c|c|c|c|c|}
\hline \multirow{3}{*}{$\frac{\text { No }}{1}$} & \multicolumn{3}{|l|}{ Pengujian } & \multirow{3}{*}{$\begin{array}{l}\text { Standar } \\
\text { SNI 3407:2008 }\end{array}$} & \multirow{2}{*}{$\begin{array}{l}\text { Nilai } \\
\text { Maks. } 12 \% \\
\end{array}$} \\
\hline & \multirow{2}{*}{\multicolumn{2}{|c|}{ Kekekalan bentuk agregat terhadap larutan }} & Natrium Sulfat & & \\
\hline & & & Magnesium Sulfat & & Maks. $18 \%$ \\
\hline \multirow[t]{4}{*}{2} & \multirow{4}{*}{$\begin{array}{l}\text { Abrasi } \\
\text { dengan } \\
\text { mesin } \\
\text { Los Angeles }\end{array}$} & Campuran AC & 100 Putaran & \multirow[t]{4}{*}{ SNI 2417:2008 } & Maks.6\% \\
\hline & & Modifikasi dan SMA & 500 Putaran & & Maks.30\% \\
\hline & & \multirow{2}{*}{$\begin{array}{l}\text { Semua jenis campuran } \\
\text { beraspal bergradasi lainnya }\end{array}$} & 100 Putaran & & Maks.8\% \\
\hline & & & 500 Putaran & & Maks. $40 \%$ \\
\hline 3 & \multicolumn{2}{|c|}{ Kelekatan agregat terhadap aspal } & & SNI 2439:2011 & Min. 95\% \\
\hline \multirow[t]{2}{*}{4} & \multirow{2}{*}{\multicolumn{2}{|c|}{ Butir pecah pada agregat kasar }} & SMA & SNI 7619:2012 & $100 / 90^{*}$ \\
\hline & & & Lainnya & & \\
\hline \multirow[t]{2}{*}{5} & \multirow{2}{*}{\multicolumn{2}{|c|}{ Partikel pipih dan lonjong }} & SMA & SNI 8287:2016 & Maks. $5 \%$ \\
\hline & & & Lainnya & Perbandingan 1:5 & Maks.10\% \\
\hline 6 & \multicolumn{3}{|c|}{ Material lolos Ayakan No.200 } & $\begin{array}{l}\text { SNI ASTM } \\
\text { C117: } 2012\end{array}$ & Maks.1\% \\
\hline
\end{tabular}

\section{Agregat Halus}

Agregat halus yaitu batuan yang lolos saringan No.8 (2,36 $\mathrm{mm})$ dan tertahan saringan No.200 $(0,075 \mathrm{~mm})$. Agregat halus terdiri dari butiran-butiran batu pecah atau pasir alam. Persyaratan spesifikasi agregat halus dapat dilihat pada Tabel 2.
Tabel 2. Ketentuan Agregat Halus

\begin{tabular}{lcl}
\hline \multicolumn{1}{c}{ Pengujian } & \multicolumn{1}{c}{ Standar } & Nilai \\
\hline Nilai setara pasir & SNI 03-4428-1997 & Min. \\
& & $50 \%$ \\
\hline $\begin{array}{l}\text { Angularitas dengan } \\
\text { uji kadar rongga }\end{array}$ & SNI 03-6877-2002 & Min. \\
\hline
\end{tabular}




\begin{tabular}{|c|c|c|}
\hline $\begin{array}{l}\text { Gumpalan Lempung } \\
\text { dan Butir- }\end{array}$ & SNI 03-4141-1996 & $\begin{array}{l}\text { Maks. } \\
1 \%\end{array}$ \\
\hline $\begin{array}{l}\text { butir mudah pecah } \\
\text { dalam agregat }\end{array}$ & & \\
\hline $\begin{array}{c}\text { Agregat lolos } \\
\text { Ayakan No.200 }\end{array}$ & $\begin{array}{l}\text { SNI ASTM C117: } \\
2012\end{array}$ & $\begin{array}{l}\text { Maks. } \\
10 \%\end{array}$ \\
\hline
\end{tabular}

\section{Filler}

Bahan pengisi yang ditambahkan harus kering dan bebas dari gumpalan dan bila diuji harus mengandung bahan yang lolos ayakan No. 200 (75 micron) tidak kurang dari $75 \%$ terhadap beratnya.

Adapun Gradasi gabungan untuk campuran beraspal, ditujukan dalam persen terhadap berat agregat dan bahan pengisi, harus memenuhi batas-batas yang diberikan seperti terlihat dalam Tabel 3.

Tabel 3. Gradasi Agregat

\begin{tabular}{|c|c|c|c|c|c|c|c|c|c|}
\hline \multirow{2}{*}{\multicolumn{2}{|c|}{ Ukuran Ayakan }} & \multicolumn{8}{|c|}{$\%$ Berat Yang Lolos terhadap Total Agregat } \\
\hline & & \multicolumn{3}{|c|}{ Stone Matrix Aspalt (SMA) } & \multicolumn{3}{|c|}{ Lataston (HRS) } & \multicolumn{2}{|c|}{ Laston (AC) } \\
\hline ASTM & $(\mathrm{mm})$ & Tipis & Halus & Kasar & $\mathrm{WC}$ & Base & $\mathrm{WC}$ & $\mathrm{BC}$ & Base \\
\hline $11 / 2 "$ & 37,5 & & & & & & & & 100 \\
\hline $1 "$ & 25 & & & 100 & & & & 100 & $90-100$ \\
\hline $3 / 4 "$ & 19 & & 100 & $90-100$ & 100 & 100 & 100 & $90-100$ & $76-90$ \\
\hline $1 / 2 "$ & 12,5 & 100 & $90-100$ & $50-80$ & $90-100$ & $90-100$ & $90-100$ & $75-90$ & $60-78$ \\
\hline $3 / 8 "$ & 9,5 & $70-95$ & $50-80$ & $25-60$ & $75-85$ & $65-90$ & $77-90$ & $66-82$ & $52-71$ \\
\hline No. 4 & 4,75 & $30-50$ & $20-35$ & $20-28$ & & & $53-69$ & $46-64$ & $35-54$ \\
\hline No. 8 & 2,36 & $20-30$ & $16-24$ & $16-24$ & $50-72$ & $35-55$ & $33-53$ & $30-49$ & $23-41$ \\
\hline No. 16 & 1,18 & $14-21$ & & & & & $21-40$ & $18-38$ & $13-30$ \\
\hline \multirow[t]{2}{*}{ No. 30} & 0,600 & $12-18$ & & & $35-60$ & $15-35$ & $14-30$ & $12-28$ & $10-22$ \\
\hline & & & & & & & & $12-28$ & \\
\hline No. 50 & 0,300 & $10-15$ & & & & & $9-22$ & $7-20$ & $6-15$ \\
\hline No. 100 & 0,150 & & & & & & $6-15$ & $5-13$ & $4-10$ \\
\hline No. 200 & 0,075 & $8-12$ & $8-11$ & $8-11$ & $6-10$ & $2-9$ & $4-9$ & $4-8$ & $3-7$ \\
\hline
\end{tabular}

\subsection{Plastik Low Density Polyethylene (LDPE)}

Pada penelitian ini menggunakan bahan aditif Plastik, yaitu plastik Low Density Polyethylene (LDPE). Plastik dapat dikelompokkan atas dua tipe, yaitu termoplastik dan thermoset (Erliza dan Sutedja, 1987). Penambahan plastik pada campuran aspal mempengaruhi nilai VMA. Agregat bergaradasi baik atau bergradasi rapat memberikan rongga antar butiran agregat (VMA) yang kecil. Hal ini disebabkan lapisan plastik telah menyelimuti agregat dan menutup Sebagian besar rongga antara butiran (Razak dan Erdiansa, 2016). Penggunaan plastik jenis LDPE ini karena sifat plastik yang paling cepat meleleh yaitu pada suhu $70^{\circ} \mathrm{C}$. Limbah Plastik yang digunakan harus hasil olahan yang telah dipilah, dicacah dan dicuci. Cacahan limbah plastik yang digunakan harus kering, bersih dan terbebas dari bahan plastik atau bahan yang tidak dikehendaki. Penggunaan limbah plastik dari 4\% sampai dengan 6\% terhadap berat aspal. Penggunaan yang lebih dari $6 \%$ harus mendapat persetujuan dari pengawas pekerjaan. Limbah plastik harus memenuhi ketentuan seperti ditunjukkan pada Tabel 4.

Tabel 4. Ketentuan Limbah Plastik Hasil Cacahan

\begin{tabular}{|c|c|}
\hline Pengujian & Persyaratan \\
\hline $\begin{array}{l}\text { Ukuran butir lolos saringan } 3 / 8 \text { inch } \\
(9,5 \mathrm{~mm}) \%\end{array}$ & 100 \\
\hline $\begin{array}{l}\text { Ukuran butir lolos saringan No } 4 \\
(4,75 \mathrm{~mm}) \%\end{array}$ & 90 \\
\hline Ketebalan (mm) & Maks. 0,07 \\
\hline Kadar Air (\%) & Maks. 5 \\
\hline Titik leleh & $100-120$ \\
\hline
\end{tabular}

\subsection{Aspal}

Aspal adalah sistem koloida yang rumit dari material hydrocarbon yang terbuat dari Asphaltenes, resin dan oil. Sedangkan material aspal tersebut berwarna coklat tua hingga hitam 
dan bersifat melekat, berbentuk padat atau semi padat yang didapat dari alam dengan penyulingan minyak (Richard, 1971). Penambahan bahan aditif jenis polimer dalam jumlah kecil ke dalam aspal terbukti dapat meningkatkan kinerja aspal dan memperpanjang umur kekuatan/masa layan perkerasan tersebut (Sengoz dan Isikyakar, 2008). Polimer juga dapat meningkatkan daya tahan perkerasan terhadap berbagai kerusakan, seperti deformasi permanen, retak akibat perubahan suhu, fatigue damage serta pemisahan/pelepasan material (Yildirim, 2007).

\subsection{Pengujian Marshall (Marshall Test)}

Pengujian Marshall adalah suatu metode pengujian untuk mengukur ketahanan stabilitas terhadap kelelehan flow dari campuran aspal dengan menggunakan alat Marshall. Adapun ketentuan sifat-sifat campuran AC-WC modifikasi dapat dilihat pada Tabel 5 .

Tabel 5. Ketentuan Sifat Campuran Beraspal Panas Laston

\begin{tabular}{|c|c|c|c|c|c|}
\hline \multirow{2}{*}{ No } & \multirow{2}{*}{ Sifat-sifat Campuran } & & \multicolumn{3}{|c|}{ Laston } \\
\hline & & & Lapis Aus & Lapis Antara & Fondasi \\
\hline 1 & Jumlah Tumbukan per bidang & Min. & & 75 & 112 \\
\hline \multirow{2}{*}{2} & \multirow{2}{*}{$\begin{array}{l}\text { Rasio partikel lolos ayakan } 0,075 \mathrm{~mm} \text { dengan kadar aspal } \\
\text { efektif }\end{array}$} & \multirow{2}{*}{ Maks. } & \multicolumn{3}{|c|}{0,6} \\
\hline & & & \multicolumn{3}{|c|}{1,6} \\
\hline \multirow{2}{*}{3} & \multirow{2}{*}{ Rongga dalam campuran (\%) (VIM) } & Min. & \multicolumn{3}{|c|}{3} \\
\hline & & Maks. & \multicolumn{3}{|c|}{5} \\
\hline 4 & Rongga dalam Agregat (\%) (VMA) & Min. & 15 & 14 & 13 \\
\hline 5 & Rongga Terisi Aspal (\%) (VFB) & Min. & 65 & 63 & 60 \\
\hline 6 & Stabilitas Marshall (kg) & Min. & \multicolumn{2}{|r|}{800} & 1800 \\
\hline \multirow{2}{*}{7} & \multirow{2}{*}{ Pelelehan (mm) (Flow) } & Min. & \multicolumn{2}{|r|}{2} & 3 \\
\hline & & Maks. & \multicolumn{2}{|r|}{4} & 6 \\
\hline \multirow{2}{*}{8} & Stabilitas Marshall sisa (\%) & \multirow{2}{*}{ Min. } & \multirow{2}{*}{\multicolumn{3}{|c|}{90}} \\
\hline & setelah perendaman 24 jam $60 \mathrm{C}(\%)$ & & & & \\
\hline \multirow{2}{*}{9} & Rongga dalam campuran (\%) pada & \multirow{2}{*}{ Min. } & \multirow{2}{*}{\multicolumn{3}{|c|}{2}} \\
\hline & kepadatan membal (refusal) & & & & \\
\hline
\end{tabular}

Sumber: (Spesifikasi Umum Bina Marga Revisi II, 2018)

\section{Stabilitas}

Stabilitas dapat dihitung dengan rumus:

$\mathrm{S}=\mathrm{p} \times \mathrm{q} \times \mathrm{r}$.....

2. Flow

Nilai Flow didapat pada pembacaan dial flow pada alat Marshall saat pengujian. Semakin rendah nilai flow menandakan campuran aspal akan semakin kaku dan getas, sehingga campuran akan mudah retak apabila terkena beban lalu lintas yang tinggi dan berat (Wantoro et al., 2013).

\section{Density}

Nilai density dihitung dengan rumus:

$\mathrm{Q}=\frac{c}{f}$

4. VIM

Nilai VIM dapat dihitung dengan rumus:

$\mathrm{VIM}=\left(100-\frac{\mathrm{Gmm} \times \mathrm{Gmb}}{\mathrm{Gmm}}\right) \%$ dari volume bulk beton aspal padat.

5. VMA

Nilai VMA dapat dihitung dengan rumus:

$\mathrm{VMA}=\left(100-\frac{G m b \times P s}{G s b}\right) \%$ dari volume bulk beton aspal padat. .

6. VFB

Nilai VFB dapat dihitung dengan rumus:

$$
\mathrm{VFB}=\frac{100(V M A-V I M)}{V M A} \% \text { dari }
$$

VMA

7. MQ

Marshall Quotient (MQ) yaitu hasil bagi stabilitas dan flow. Nilai MQ dinyatakan dalam kg/mm (Hardiatmo, 2007). 


\section{METODE PENELITIAN}

Persiapan alat dan bahan, Adapun bahan terdiri dari aspal, limbah plastik Low density Polyethylene (LDPE), agregat kasar, agregat halus dan filler. Pada aspal pengujian yang dilakukan adalah penetrasi, titik lembek, titik nyala, berat jenis dan daktilitas. Pada agregat kasar pengujian yang dilakukan adalah analisis saringan, berat jenis, penyerapan air, dan keusan agregat kasar. Pada agregat halus dan filler pengujian yang dilakukan adalah analisis saringan, berat jenis dan pennyerapana air. Jika semua pengujian telah memenuhi spesifikasi maka akan dilanjutkan dengan penentuan kadar optimum aspal (KAO). pembuatan benda uji dengan variasi kadar palstik 0\%, 3\%, 6\%, 9\%, $12 \%$, dan $20 \%$. Dilakukan pengumpukan data dan analisis perhitungan kemudian kesimpulan dari penelitian.

Jumlah sampel yang digunakan untuk mencari KAO yaitu seperti pada Tabel 6 .

Tabel 6. Rincian Banyak Sampel Aspal KAO

\begin{tabular}{cc}
\hline Kadar Aspal (\%) & Jumlah Sampel \\
\hline 5 & 2 \\
\hline 6 & 2 \\
\hline 7 & 2 \\
\hline Jumlah & 6 \\
\hline
\end{tabular}

Jumlah sampel aspal dengan campuran plastik LDPE ditunjukkan pada Tabel 7.

Tabel 7. Rincian Banyak Sampel Aspal dengan Tambahan Plastik LDPE

\begin{tabular}{cc}
\hline Kadar Aspal (\%) & Jumlah Sampel \\
\hline 0 & 2 \\
\hline 3 & 2 \\
\hline 6 & 2 \\
\hline 9 & 2 \\
\hline 12 & 2 \\
\hline 20 & 2 \\
\hline Jumlah & $\mathbf{1 2}$ \\
\hline
\end{tabular}

Maka jumlah sampel yang diperlukan seluruhnya adalah sebanyak 18 buah.

\section{HASIL DAN PEMBAHASAN}

\subsection{Pengujian Aspal}

\section{Pengujian Penetrasi Aspal}

Didapat hasil bacaan pada alat penetrasi yaitu 63, 65, 64, 67, 66 sehingga nilai penetrasi rata-rata aspal yang diuji adalah 65.

\section{Pengujian Daktilitas Aspal}

Pada pengujian ini Panjang benda uji yaitu $103 \mathrm{~cm}$.

\section{Pengujian Berat Jenis Aspal}

Dalam pengujian ini didapatkan besar Berat Jenis Aspal adalah 1,046 gram.

\section{Pengujian Titik Lembek Aspal}

Dari hasil pengujian titik lembek didapatkan nilai suhu aspal mencapat titik lembeknya yaitu pada benda uji 1 sebesar $63^{\circ} \mathrm{C}$ dan benda uji $264^{\circ} \mathrm{C}$ dengan selisih $1{ }^{\circ} \mathrm{C}$ dan rata-rata yaitu $63,5^{\circ} \mathrm{C}$.

\section{Pengujian Titik Nyala dan Titik Bakar Apal} Dari hasil pengujian titik nyala dan titik bakar didapatkan suhu titik nyala adalah $305^{\circ} \mathrm{C}$ dan suhu titik bakar adalah $308^{\circ} \mathrm{C}$.

\subsection{Pengujian Agregat Kasar}

\section{Pengujian Analisis Saringan}

Pengujian ini untuk pemeriksaan dan menentukan pembagian butir (gradasi) agregat kasar dengan menggunakan satu set saringan seperti pada Tabel 8.

Tabel 8. Analisis Saringan Agregat Kasar

\begin{tabular}{ccccc}
\hline Sieve & Retained & Cummulative & \multicolumn{2}{c}{ Percent } \\
\cline { 2 - 5 } No. & Weight (gr) & Retained (gr) & Retained & Pass \\
\hline$\# 1$ & 0 & 0 & 0 & 100 \\
\hline$\# 3 / 4$ & 0 & 0 & 0 & 100 \\
\hline$\# 1 / 2$ & 244 & 244 & 12,20 & 87,80 \\
\hline$\# 3 / 8$ & 381,2 & 625 & 31,26 & 68,74 \\
\hline$\# 4$ & 463,5 & 1089 & 54,44 & 45,57 \\
\hline$\# 8$ & 536,3 & 1625 & 81,25 & 18,75 \\
\hline$\# 16$ & 223,7 & 1849 & 92,44 & 7,57 \\
\hline$\# 30$ & 107 & 1956 & 97,79 & 2,22 \\
\hline$\# 50$ & 35 & 1991 & 99,54 & 0,47 \\
\hline$\# 100$ & 8,4 & 1999 & 99,96 & 0,05 \\
\hline$\# 200$ & 0,9 & 2000 & 100,00 & 0,00 \\
\hline PAN & 0 & 2000 & 100,00 & 0,00 \\
\hline & & & &
\end{tabular}




\section{Pengujian Berat Jenis dan Penyerapan Air Agregat Kasar}

Dari percobaan berat jenis agregat kasar (CA) Awang Bangkal didapatkan berat jenis (Bulk) sebesar 2,56 gr, berat jenis kering permukaan jenuh (SSD) sebesar 2,63 gr, berat jenis semu adalah 2,70 gr dan penyerapan airnya sebesar $0,015(<3 \%)$.

\section{Pengujian Keausan Agregat}

Pada pengujian ini berat benda uji sebesar 5000 gr menggunakan grading $\mathrm{B}$, dalam pengujiannya benda uji no 1 yaitu berat benda uji tertahan saringan No.1/2 adalah 2500 gr, berat lolos saringan No.1/2 adalah 2500 gr, persentase keausan adalah $32 \%$.

\subsection{Pengujian Agreat Halus}

\section{Pengujian Berat Jenis dan Penyerapan Air Agregat Halus}

Dari percobaan berat jenis agregat halus pasir Cempaka didapatkan berat jenis (Bulk) sebesar $1,82 \mathrm{gr}$, berat jenis kering permukaan jenuh (SSD) sebesar 2,07 gr, berat jenis semu adalah 2,30 gr dan penyerapan airnya sebesar $0,116(<3 \%)$.

\section{Pengujian Analisis Saringan}

Pengujian ini untuk pemeriksaan dan menentukan pembagian butur (gradasi) agregat halus yaitu pasir Cempaka dengan menggunakan satu set saringan seperti pada Tabel 9 .

Tabel 9. Analisis Saringan Agregat Halus

\begin{tabular}{ccccc}
\hline \multirow{2}{*}{$\begin{array}{c}\text { Sieve } \\
\text { No. }\end{array}$} & Retained & Cummulative & \multicolumn{2}{c}{ Percent } \\
\cline { 2 - 5 }$\#$ Weight (gr) & Retained (gr) & Retained & Pass \\
\hline$\# 1$ & 0 & 0 & 0 & 100 \\
\hline$\# 3 / 4$ & 0 & 0 & 0 & 100 \\
\hline$\# 1 / 2$ & 0 & 0 & 0 & 100 \\
\hline$\# 3 / 8$ & 0 & 0 & 0 & 100 \\
\hline$\# 4$ & 0 & 0 & 0 & 100 \\
\hline$\# 8$ & 67 & 67 & 6,70 & 93,30 \\
\hline$\# 16$ & 254 & 321 & 32,10 & 67,90 \\
\hline$\# 30$ & 374,6 & 695,6 & 69,56 & 30,44 \\
\hline$\# 50$ & 98 & 793,6 & 79,36 & 20,64 \\
\hline$\# 100$ & 122,4 & 916 & 91,60 & 8,40 \\
\hline$\# 200$ & 84 & 1000 & 100,00 & 0 \\
\hline PAN & 0 & 1000 & 100,00 & 0 \\
\hline
\end{tabular}

\subsection{Pengujian Filler}

\section{Pengujian Analisis Saringan}

Pengujian ini untuk pemeriksaan dan menentukan butir (gradasi) Filler yaitu dari Abu Batu dengan menggunakan satu set saringan seperti pada Tabel 10.

Tabel 10. Analisis Saringan Filler

\begin{tabular}{ccccc}
\hline \multirow{2}{*}{$\begin{array}{c}\text { Sieve } \\
\text { No. }\end{array}$} & $\begin{array}{c}\text { Retained } \\
\text { (gr) }\end{array}$ & Cummulative & \multicolumn{2}{c}{ Percent } \\
\hline$\# 1$ & 0 & 0 & 0 & 100 \\
\hline$\# 3 / 4$ & 0 & 0 & 0 & 100 \\
\hline$\# 1 / 2$ & 0 & 0 & 0 & 100 \\
\hline$\# 3 / 8$ & 0 & 0 & 0 & 100 \\
\hline$\# 4$ & 0 & 0 & 0 & 100 \\
\hline$\# 8$ & 0 & 0 & 0 & 100 \\
\hline$\# 16$ & 0 & 0 & 0 & 100 \\
\hline$\# 30$ & 0 & 0 & 0 & 100 \\
\hline$\# 50$ & 0 & 0 & 0 & 100 \\
\hline$\# 100$ & 0 & 0 & 0 & 100 \\
\hline$\# 200$ & 235 & 235 & 30,7189 & 69,28105 \\
\hline PAN & 765 & 765 & 100 & 0 \\
\hline
\end{tabular}

\section{Pengujian Berat Jenis dan Penyerapan Air Filler}

Dari percobaan berat jenis Filler didapatkan berat jenis (Bulk) sebesar 2,04 gr, berat jenis kering permukaan jenuh (SSD) sebesar 2,24 gr, berat jenis semu adalah 2,66 gr dan penyerapan airnya sebesar $0,114(<3 \%)$. Agregat halus sudah memenuhi ketentuan mutu pasal 6.3.2(1) yaitu penyerapan air oleh agregat maksimum 3\%.

\subsection{Gradasi Agregat Gabungan}

Persentase masing-masing agregat dapat dilihat pada Gambar 1 dan Tabel 11.

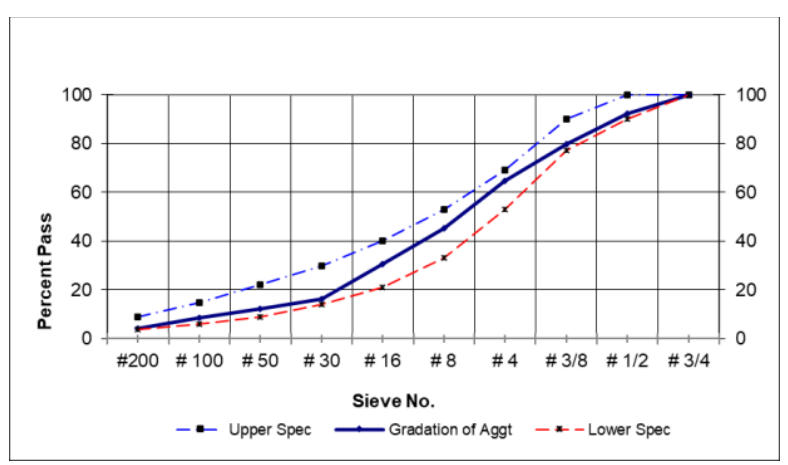

Gambar 1. Grafik Gradasi Gabungan Aspal AC-WC 
Tabel 11. Gradasi Agregat Gabungan

\begin{tabular}{ccccccccc}
\hline No. & \multicolumn{2}{c}{ Agregat Kasar } & \multicolumn{2}{c}{ Agregat Halus } & \multicolumn{2}{c}{ Filler } & Jumlah & Spec. \\
\hline Saringan & \multicolumn{2}{c}{$65 \%$} & \multicolumn{2}{c}{$29 \%$} & \multicolumn{2}{c}{$6 \%$} & Total & Gradasi \\
\hline & Lolos & \multicolumn{2}{c}{ Lolos } & Lolos & & & \\
\hline$\# 3 / 4$ & 100 & 65 & 100 & 29 & 100 & 6 & 100,00 & 100 \\
\hline$\# 1 / 2$ & 87,80 & 57,07 & 100 & 29 & 100 & 6 & 92,07 & $90-100$ \\
\hline$\# 3 / 8$ & 68,74 & 44,68 & 100 & 29 & 100 & 6 & 79,68 & $77-90$ \\
\hline$\# 4$ & 46 & 29,62 & 100 & 29 & 100 & 6 & 64,62 & $53-69$ \\
\hline$\# 8$ & 18,75 & 12,19 & 93 & 27,06 & 100 & 6 & 45,24 & $33-53$ \\
\hline$\# 16$ & 7,57 & 4,92 & 68 & 19,69 & 100 & 6 & 30,61 & $21-40$ \\
\hline$\# 30$ & 2,22 & 1,44 & 30,44 & 8,83 & 100 & 6 & 16,27 & $14-30$ \\
\hline$\# 50$ & 0,47 & 0,30 & 20,64 & 5,99 & 100 & 6 & 12,29 & $9-22$ \\
\hline$\# 100$ & 0,0 & 0,03 & 8,4 & 2,44 & 100 & 6 & 8,47 & $6-15$ \\
\hline$\# 200$ & 0,00 & 0 & 0,00 & 0 & 69,28 & 4,156863 & 4,16 & $4-9$ \\
\hline
\end{tabular}

\subsection{Pengujian Marshall untuk Mendapatkan Nilai KAO}

Nilai karakteristik aspal AC-WC dapat dilihat pada Tabel 12.

Tabel 12. Nilai Karakteristik Aspal AC-WC

\begin{tabular}{cccc}
\hline Karakteristik & \multicolumn{3}{c}{ Kadar Aspal } \\
\hline Campuran & $5 \%$ & $6 \%$ & $7 \%$ \\
\hline VIM (\%) & 5,47 & 3,86 & 3,72 \\
\hline VMA (\%) & 16,1 & 16,73 & 18,64 \\
\hline VFB (\%) & 67,96 & 79,69 & 83,41 \\
\hline Stabilitas (Kg) & 1160,78 & 1575,17 & 1117,83 \\
\hline Flow (mm) & 3,65 & 3,57 & 3,255 \\
\hline MQ (Kg/mm) & 318,68 & 443,97 & 343,82 \\
\hline
\end{tabular}

Kadar aspal optimum didapatkan sebesar 6,125\%, seperti pada Gambar 2.

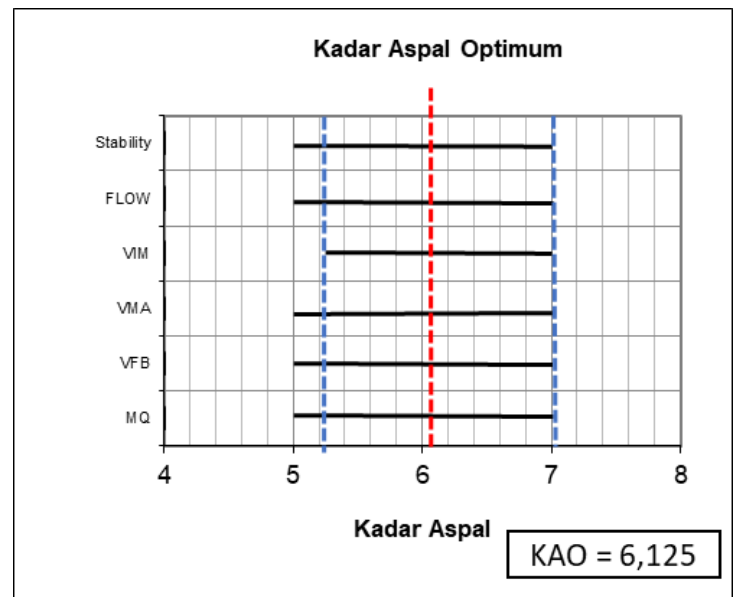

Gambar 2. Kadar Aspal Optimum AC-WC

Hasil dari garfik hubungan antara kadar aspal optimum dan campuran aspal AC-Wearing Course sesuai Spesifikasi Umum Bina Marga Tahun 2018 bisa dilihat pada Tabel 13.

Tabel 13. Hasil Karakteristik Kadar Aspal Optimum Campuran Aspal AC-WC

\begin{tabular}{cccc}
\hline Karakteristik Campuran & Spesifikasi & KAO (6,125\%) & Ket \\
\hline VIM & $3 \%-5 \%$ & 3,8 & Memenuhi \\
\hline VMA & Min $15 \%$ & 16,9 & Memenuhi \\
\hline VFB & Min $65 \%$ & 81 & Memenuhi \\
\hline Stabilitas & Min $800 \mathrm{Kg}$ & 1550 & Memenuhi \\
\hline Flow & $2 \mathrm{~mm}-4 \mathrm{~mm}$ & 3,5 & Memenuhi \\
\hline MQ & Min $80 \mathrm{Kg} / \mathrm{mm}$ & 445 & Memenuhi \\
\hline
\end{tabular}




\subsection{Analisis Karakteristik Campuran Laston (AC-WC) dengan Plastik LDPE \\ Berikut dibawah ini adalah hasil} perhitungan hubungan kadar aspal AC-Wearing Course (AC-WC) terhadap sifat marshall menggunakan plastik dengan kadar optimum $6,125 \%$ dan rentang campuran plastik yaitu $0 \%$,
$3 \%, 6 \%, 9 \%, 12 \%$ dan $20 \%$ terhadap berat aspal. Pada penelitian ini dari kadar plastik 3\% -12\% masih masuk spesifikasi terapi pada kadar plastik $20 \%$ nilai VIM dan VFB tidak memenuhi persyaratan Spesifikasi Umum Bina Marga 2018 seperti pada Tabel 14.

Tabel 14. Hasil Pengujian Marshall dengan Campuran Plastik

\begin{tabular}{|c|c|c|c|c|c|c|c|c|}
\hline \multirow[t]{2}{*}{ No. } & \multirow{2}{*}{$\begin{array}{c}\text { Jenis } \\
\text { Pemeriksaan }\end{array}$} & \multicolumn{6}{|c|}{ Kadar Plastik } & \multirow[t]{2}{*}{ Spesifikasi } \\
\hline & & $0 \%$ & $3 \%$ & $6 \%$ & $9 \%$ & $12 \%$ & $20 \%$ & \\
\hline 1 & Density $(\mathrm{g} / \mathrm{cm} 3)$ & 2,165 & 2,163 & 2,159 & 2,153 & 2,149 & 2,074561 & - \\
\hline 2 & Stability (kg) & 1567,023 & 1574,682 & 1586,050 & 1718,714 & 1843,357 & 1798,723 & Min. $800 \mathrm{~kg}$ \\
\hline 3 & Flow $(\mathrm{mm})$ & 3,94 & 3,95 & 3,785 & 3,745 & 3,74 & 3,61 & $2-4 \mathrm{~mm}$ \\
\hline 4 & $\begin{array}{l}\text { Marshall } \\
\text { Quotient } \\
(\mathrm{kg} / \mathrm{mm})\end{array}$ & 398,262 & 399,623 & 419,182 & 459,288 & 492,886 & 498,2449 & $\begin{array}{l}\text { Min. } 80 \\
\mathrm{~kg} / \mathrm{mm}\end{array}$ \\
\hline 5 & VMA (\%) & 16,441 & 16,518 & 16,664 & 16,898 & 17,040 & 19,80968 & Min. $15 \%$ \\
\hline 6 & VFB (\%) & 83,297 & 82,843 & 81,961 & 80,609 & 79,789 & 64,80441 & Min. $65 \%$ \\
\hline 7 & $\operatorname{VIM}(\%)$ & 3,228 & 3,317 & 3,487 & 3,757 & 3,922 & 7,414381 & $3-5 \%$ \\
\hline
\end{tabular}

\section{Density (Kepadatan)}

Adanya penambahan plastik LDPE pada campuran aspal AC-WC menyebabkan terjadinya penurunan nilai density (Kepadatan), dapat dilihat pada Gambar 3.

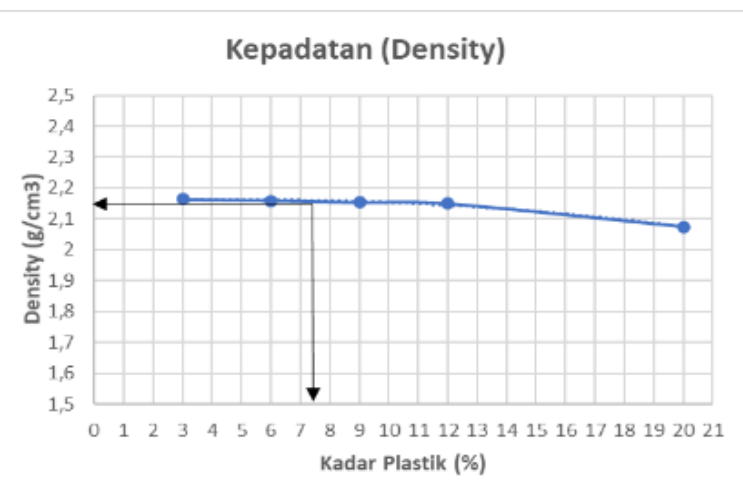

Gambar 3. Grafik Hubungan Antara Density dengan Kadar Plastik

\section{Stabilitas}

Adanya penambahan plastik LDPE pada campuran aspal AC-WC menyebabkan terjadinya peningkatan nilai stabilitas sampai kadar palstik $12 \%$, Namun diperlukan pembatasan dalam penggunaan plastik LDPE karena terjadi penurunan pada penambahan kadar $20 \%$, seperti pada Gambar 4.

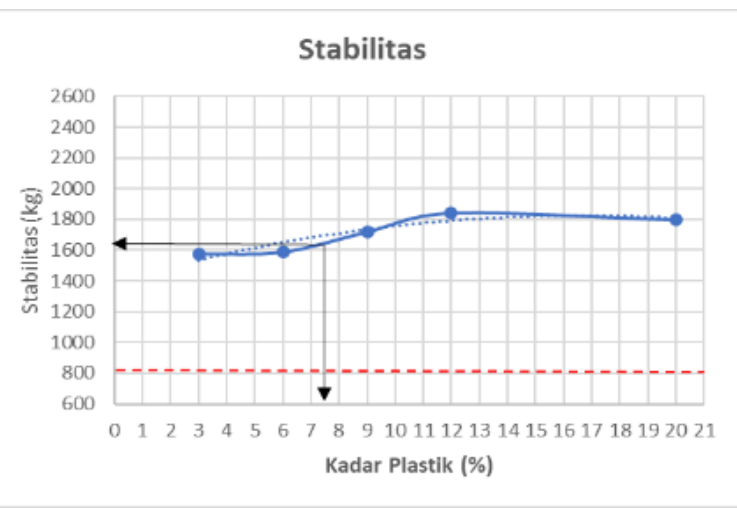

Gambar 4. Grafik Hubungan Antara Stabilitas dengan Kadar Plastik

\section{Flow}

Semakin tinggi penambahan kadar campuran plastik LDPE semakin rendah nilai flow yang diperoleh, seperti pada Gambar 5. 


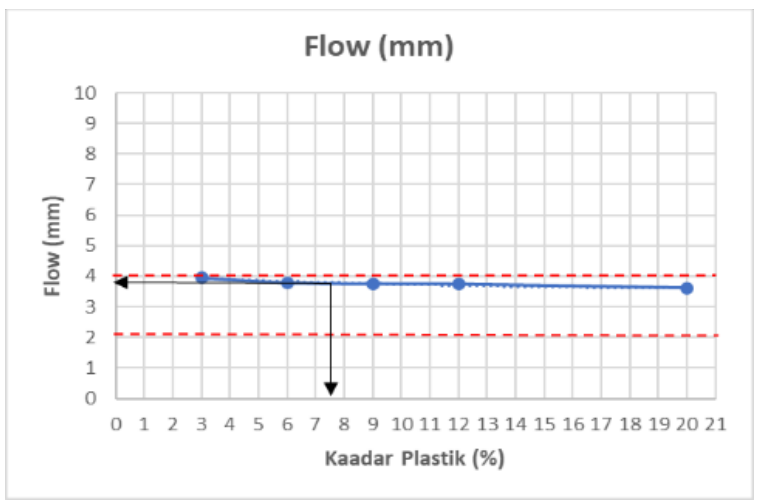

Gambar 5. Grafik Hubungan Antara Flow dengan Kadar Plastik

\section{Rongga dalam Campuran (VIM)}

Semakin tinggi kadar plastik LDPE maka semakin tinggi nilai VIM yang diperoleh, dengan penambahan kadar $20 \%$ nilai VIM tidak memenuhi spesifikasi,.seperti pada Gambar 6.

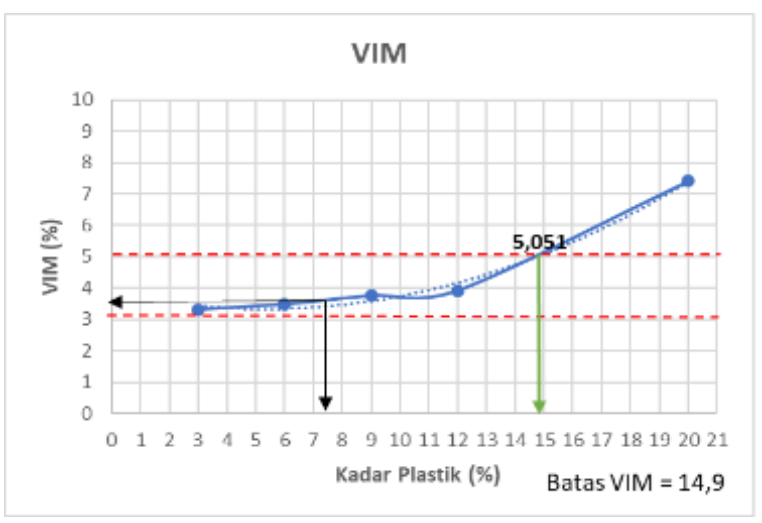

Gambar 6. Grafik Hubungan Antara VIM dengan Kadar Palstik

\section{Rongga dalam Agregat (VMA)}

Pada umumnya nilai VMA berbanding lurus dengan nilai VIM dimana VMA terus meningkat, seperti pada Gambar 7.

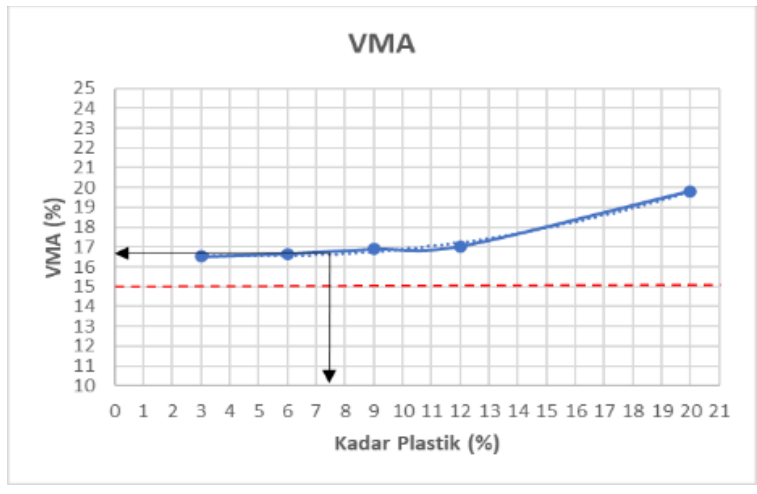

Gambar 7. Grafik Hubungan Antara VMA dengan Kadar Plastik

\section{Rongga Terisi Aspal (VFB)}

Semakin tinggi kadar plastik LDPE maka semakin rendah nilai VFB, tetapi dengan penambahan kadar plastik 20\% nilai VFB tidak memenuhi spesifikasi ,seperti pada Gambar 8.

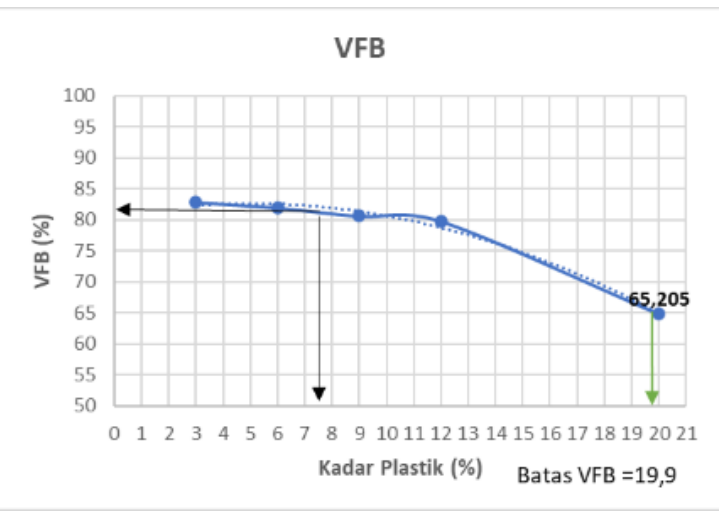

Gambar 8. Grafik Hubungan Antara VFB dengan Kadar Plastik

\section{Hasil Bagi Marshall (MQ)}

Semakin tinggi kadar plastic LDPE maka semakin tinggi nilai MQ, seperti pada Gambar 9. 


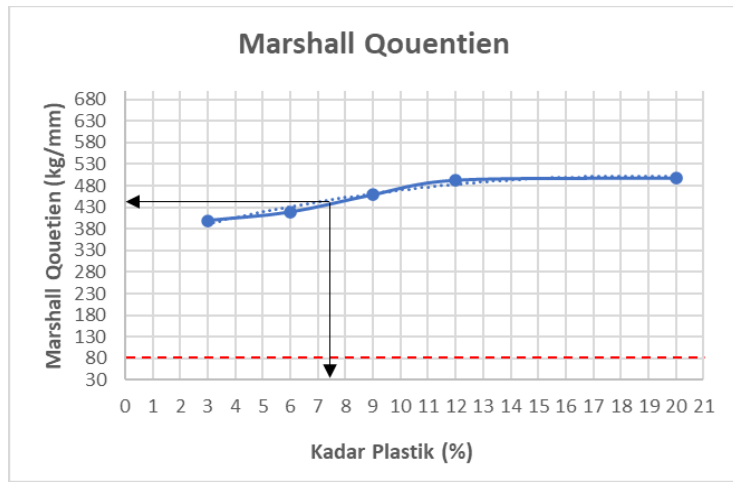

Gambar 9. Grafik Hubungan Antara MQ dengan Kadar Plastik

Adapun nilai optimum plastik LDPE dari hasil perhitungan marshall adalah didapatkan sebesar 7,45\% seperti pada Gambar 10 .

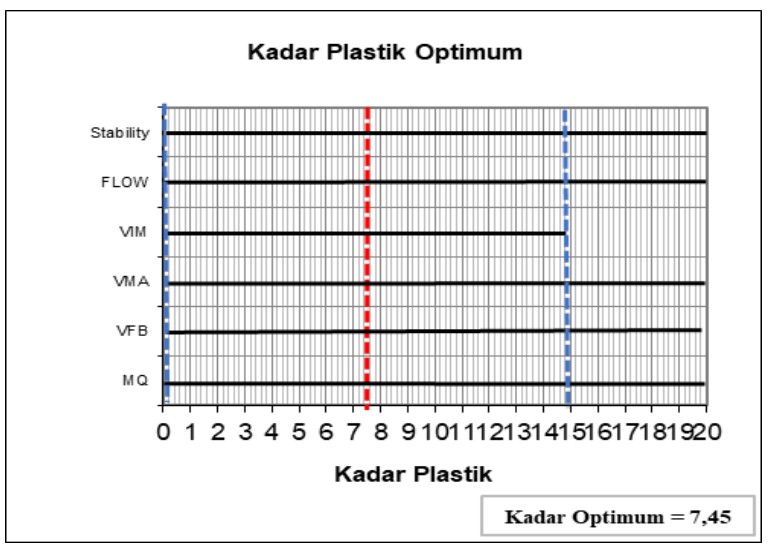

Gambar 10. Kadar Optimum Plastik LDPE

Adapun Perbandingan karakteristik campuran tanpa menggunakan plastik dan yang menggunalan palstik LDPE, seperti terlihat pada Tabel 15.

Tabel 15. Perbandingan Antara Aspal Biasa dengan Aspal Plastik

\begin{tabular}{cccc}
\hline No. & Karakteristik & $\begin{array}{c}\text { Tanpa } \\
\text { Plastik 0\% }\end{array}$ & $\begin{array}{c}\text { Plastik } \\
\text { LDPE }\end{array}$ \\
\hline 1 & Density & 2,165 & 2,161 \\
\hline 2 & VIM (\%) & 1567,023 & 1693,976 \\
\hline 3 & VMA (\%) & 3,94 & 3,792 \\
\hline 4 & VFB (\%) & 3,228 & 3,416 \\
\hline 5 & Stabilitas (Kg) & 16,441 & 16,618 \\
\hline 6 & Flow (mm) & 83,297 & 82,15 \\
\hline 7 & MQ $(\mathrm{Kg} / \mathrm{mm})$ & 398,262 & 447,085 \\
\hline
\end{tabular}

\section{KESIMPULAN}

Dari hasil penelitian pada campuran aspal AC-WC dengan campuran plastik LDPE dengan menggukan Spesifikasi Umum Bina Marga 2018, diperoleh NNilai optimum kadar aspal AC-WC setelah dilakukan pengujian marshall didapatkan sebesar 6,125\% dan nilai optimum aspal AC-WC dengan campuran plastik LDPE didapatkan sebesar 7,45\%.

Perbandingan hasil uji marshall antara aspal AC-WC tanpa menggunakan campuran plastik DPE $(0 \%)$ dengan aspal menggunakan campuran plastik LDPE (3\%, 6\%, 9\%, 12\%, dan 20\%) didapat nilai density, Flow dan VFB aspal tanpa campuran plastik lebih besar dibandingkan aspal dengan campuran plastik. Sedangkan Nilai stabilitas, VIM, VMA, dan MQ aspal tanpa menggunakan plastik lebih kecil dibandingkan dengan campuran plastik.

\section{DAFTAR PUSTAKA}

Direktorat Jendral Bina Marga. 2018. Perkerasan Lentur Jalan Raya. Spesifikasi Umum Divisi 6.

Erliza dan Sutedja. 1987. Pengantar Pemanasan. Laboratorium Pengemasan, Jurusan TIP. IPB. Bogor.

Gunawan. 2001. Pengaruh Penambahan Sampah Plastik Keras Dalam Aspal Sebagai Bahan Aditif Pada Campuran Lapis Aspal Beton (LASTON). Universitas Tanjungpura. Pontianak.

Hardiatmo, H.C., 2007. Pemeliharaan Jalan Raya, Gadjah Mada University Press, Yogyakarta.

Jenna R. Jambeck. 2010 Environmental Engineering, College of Engineering University of Georgia.

Razak, Bustamin Abdul., dan Erdiansa, Andi. 2016. Karakteristik Campuran AC-WC dengan Penambahan Limbah Plastik Low Density Polyethylene (LDPE). Jurnal Teknik Sipil Politeknik Negeri Ujung Pandang.

Richard D, Walker. 1971. Highway materials. McGraw Hill Book Company. 
Sengoz, B.,dan Isikyakar, G. 2008. Analysis Of Styrene-Butadiene-Styrene Polymer Modified Bitumen using Fluorescent Microscopy and Conventional Test Methods. J Hazard Mater.

Sukirman, Silvia. 2003. Beton Aspal Campuran Panas. Jakarta. Yayasan Obor Indonesia.

Wantoro, Widi, et al. 2013. Pengaruh Penambahan Plastik Bekas tipe Low Density Polyethylene (LDPE) Terhadap Kinerja Campuran Beraspal. Jurusan Jurusan Teknik Sipil, Fakultas Teknik Universitas Diponegoro, Semarang.
Yildirim, Y. 2005. Polymer Modified Asphalt Binders. Journal of Construction and Building Materials 21 (2007), 66-72. 